TEME, г. XLIV, бр. 4, октобар - децембар 2020, стр. 1515-1532

\begin{tabular}{lr}
\hline \hline Оригинални научни рад & https://doi.org/10.22190/TEME190430089S \\
Примљено: 30. 4. 2019. & UDK 623.44:343.61(497.11) \\
Ревидирана верзија: 8. 9. 2019. & $316.356 .2: 316.624$ \\
Одобрено за штампу: 1. 12. 2020. &
\end{tabular}

\title{
КОНТРОЛА ВАТРЕНОГ ОРУЖЈА И РОДНО ЗАСНОВАНО НАСИЉЕ: ЛИНК КОЈИ НЕДОСТАЈЕ?
}

\author{
Данијела Спасић \\ Криминалистичко-полицијски универзитет, Београд, Република Србија \\ danijela.spasic@kpu.edu.rs
}

\begin{abstract}
Апстракт
Почетком 2000-их година процене су указивале на присуство преко милион комада ватреног оружја и велике количине муниције у поседу грађана Србије. Истовремено, демографија насиља у породици упозоравала је на последице злоупотребе ватреног оружја у контексту породичног и партнерског насиља. Велики број убистава жена (годишње између 30 и 40) покренуо је и питање поседовања (не)легалног оружја, али и адекватног реаговања институција спречавањем насиља са смртним исходом. На основу чињенице да је Србија донела Закон о оружју и муницији 2015. године, да је 2013. ратификовала Истанбулску конвенцију и усвојила Закон о спречавању насиља у породищи 2016. и статистике убистава жена у контексту насиља у породици, аналитички приступ у раду усмерен је на тражење одговора на питање Предвиђа ли постојећи законодавни оквир заштиту жртава насиља од злоупотребе ватреног оружја?. Налази истраживања указују на потребу унапређења кохерентности законодавног одговора на ризике узроковане присуством ватреног оружја у контексту насиља, али и на успостављање јачих веза између законодавног оквира контроле ватреног оружја и закона којима се регулише одговор на насиље у породици и партнерско насиље.
\end{abstract}

Кључне речи: ватрено оружје, родно засновано насиље, законодавни оквир, Србија.

\section{FIREARMS CONTROL AND GENDER-BASED VIOLENCE: THE MISSING LINK?}

\begin{abstract}
In the early 2000s, estimates indicated the presence of over a million pieces of firearms and a large amount of ammunition in the possession of Serbian citizens. At the same time, the demographics of domestic violence pointed to the consequences of the misuse of firearms in the context of family and partner violence. A large number of women's killings (annually between 30 and 40) also raised the issue of possession of (non) legal weapons, as well as the adequate response of institutions in preventing fatal outbreaks. On the basis of the fact that Serbia passed the Law on Weapons and Ammunition in 2015, in 2013 it
\end{abstract}


ratified the Istanbul Convention and adopted the Law on the Prevention of Domestic Violence in 2016, and the statistics on the death by murder of women in the context of domestic violence, the analytical approach in the paper focuses on seeking the answer to the question: whether the existing legislative framework provides for the protection of victims of violence against the misuse of firearms? The findings of study indicate the need to enhance the coherence of the legislative response to the risks posed by the presence of firearms in the family context, as well as establishing stronger links between the legislative framework for the control of firearms and the laws governing the response to domestic violence and partner violence.

Key words: $\quad$ firearms, domestic violence, legal framework, Serbia.

\section{УВОД - РОД И ОРУЖЈЕ}

Глобалне политике о контроли лаког ватреног оружја (енгл. SALW - Small Arms and Light Weapons), али и истраживања о малокалибарском наоружањ ${ }^{1}$ - углавном су игнорисали значај полних разлика и рода у обликовању друштвених ставова и понашања према ватреном оружју, ретко су се бавили анализама околности у којима мушкарци и жене постају жртве, односно питањем ко поседује оружје и најчешће га користи. Утицај родних разлика на поседовање оружја и оружано насиље постаје посебно значајан кад се разматра њихова улога у „контексту без конфликта”, као што су породично или партнерско насиље. У многим културама поседовање оружја снажно је повезано са традиционалним појмовима мушкости, ауторитета, привилегија, престижа и моћи, или се оправдава традиционалном улогом мушкарца да штити своју породицу.

Анализе социолошких и културолошких фактора ризика за насиље и убиство жена указују на културу „мачизма”, која мења традиционалне родне улоге и подстиче ограничења слободе девојака и жена, мизогино понашање и некажњивост насиља (UNGA, 1993). Родна неједнакост се повезује са концептима моћи и мушкости и културним ставовима који ограничавају мобилност и понашање жена, док уочена трансгресија прихваћених улога од стране жена може изазвати насилне реакције мушкараца (Богетић, Митровић, Николић, 2018, стр. 755). Симболика моћи везана за оружје има свој еквивалент у „насилној мушкости”, као културолошком контексту у којем

\footnotetext{
${ }^{1}$ Појмови ватрено оружје, оружје и лако и малокалибарско оружје биће коришћени као синоними у тексту. Термин малокалибарско оружје и лако наоружање (SALW) односи се на конвенционално оружје које је релативно јефтино и лако доступно, једноставно за употребу и одржавање. То је основно оружје које се користи у већини сукоба и оружаног насиља, „право оружје масовног уништења”, посебно узимајући у обзир његову велику доступност у оквиру изузетно развијених нелегалних токова, које је тешко контролисати (Котарлић, Јоксимовић, 2015, стр. 252).
} 
се оружје користи као средство застрашивања и психичке контроле у непрекидном циклусу родно заснованог насиља над женама.

Процене социјалних и економских трошкова оружаног насиља истичу губитке у продуктивности мушкараца који зарађују у формалној економији (Florquin, 2006; Geneva Declaration Secretariat, 2008). Међутим, последице убистава жена и сексуалног насиља на женску радну снагу и шире тржиште рада ретко се узимају у обзир. Ипак, постоји све више доказа да култура насиља може допринети „феминизацији сиромаштва” и даљој маргинализацији жена у друштву (PАНО, 2005). Шире гледано, оружано насиље - посебно насиље према женама - представља озбиљан изазов за развој.

Узимајући у обзир изнете чињенице, аналитички приступ у овом раду усмерен је на тражење одговора на питање Предвиђа ли постојећи законодавни оквир у Србији заштиту жртава насиьа од злоупотребе ватреног оружја?. Истраживање је конципирано тако да се на основу доступних података из претходних истраживања најпре процењује распрострањеност ватреног оружја и његова злоупотреба у контексту насиља над женама, а потом анализира законски оквир који у Србији дефинише ову област. Уочене празнине у законском регулисању или неадекватна друштвена реакција на овај проблем - биће предмет посебних препорука у закључним разматрањима.

\section{„ОРУЖЈЕ НА МЕТИ”: ДОСТУПНОСТ ВАТРЕНОГ ОРУЖЈА}

Иако је познато да оружје само по себи не изазива конфликте, искуство показује да присуство оружја погоршава сукобе и повећава ризик за цивилно становништво. Након формалног прекида ватре, свеприсутност поседовања оружја у једном постконфликтном друштву рефлектује бројне друштвене проблеме и процесе - од процеса помирења и изградње мира, преко људских права и положаја рањивих група, па све до пораста насиља (Cukier, 2002).

Процене о количини лаког и малокалибарског оружја показују да је у свету присутно негде око 875 милиона комада малокалибарског оружја у поседу цивила, 22,7 милиона у поседу полицијских служби и 133 милиона у поседу оружаних снага (Karp, 2018, p. 4). Када је реч о броју комада оружја у односу на број становника, Република Србија дели треће место са Црном Гором, одмах након Јемена и Сједињених Америчких Држава (Табела 1).

Према проценама Small Arms Survey (SAS) из 2018. године (Karp, 2018), у Албанији, Босни и Херцеговини, Црној Гори, Македонији и Србији има више од 6 милиона комада оружја (у просеку 30 комада оружја на 100 становника). Скоро 90\% оружја је у рукама грађана, што је изнад светског просека, који износи око 75\%. Процењује се да у региону Западног Балкана између 500 хиљада и 1,6 милиона домаћинстава 
поседује ватрено оружје. Србија и Црна Гора су лидери и у овој области. На сваких 100 становника у ове две земље долази скоро 40 комада лаког наоружања (Табела 2). Процена је да у Србији има преко 1,5 милиона нелегалног и 1,1 легалног оружја (Karp, 2018).

Табела 1. Прочена броја комада оружја на 100 становника

\begin{tabular}{lrllll}
\hline САД & 120,5 & Исланд & 31,7 & Шведска & 23,1 \\
Јемен & 52,8 & Босна и Херцеговина & 31,2 & Пакистан & 22,3 \\
Црна Гора & 39,1 & Аустрија & 30,0 & Португал & 21,3 \\
Србија & $\mathbf{3 9 , 1}$ & Северна Македонија & 29,8 & Француска & 19,6 \\
Канада & 34,7 & Норвешка & 28,8 & Немачка & 19,6 \\
Уругвај & 34,7 & Малта & 28,3 & Ирак & 19,6 \\
Кипар & 34,0 & Швајцарска & 27,6 & Луксембург & 18,9 \\
Финска & 32,4 & Нови Зеланд & 26,3 & & \\
\hline
\end{tabular}

Табела 2. Прочена броја комада оружја на Западном Балкану

\begin{tabular}{|c|c|c|c|c|c|c|}
\hline Број комада оружја & Војска & Полиција & $\begin{array}{c}\text { Цивили } \\
\text { (укупно) }\end{array}$ & $\begin{array}{c}\text { Цивили } \\
\text { (легално) }\end{array}$ & $\begin{array}{c}\text { Цивили } \\
\text { (нелегално) }\end{array}$ & $\begin{array}{c}\text { На } 100 \\
\text { становника }\end{array}$ \\
\hline Албанија & 21.750 & 19.000 & 350.000 & 65.747 & 284.253 & $13,03 \mathbf{\nabla}$ \\
\hline Босна и Херцеговина & 27.300 & 29.000 & 1.185 .000 & 353.000 & 832.000 & $31,24 \boldsymbol{\Delta}$ \\
\hline Црна Гора & 5396 & 8000 & 245.000 & 103.536 & 141.464 & $39,14 \boldsymbol{\Delta}$ \\
\hline Македонија & 29.530 & 21.000 & 621.000 & 169.687 & 451.313 & $29,79 \boldsymbol{\Delta}$ \\
\hline Србија & 384.422 & 53.100 & 2.719 .000 & 1.186 .086 & 1.532 .914 & $39,14 \boldsymbol{\Delta}$ \\
\hline Укупно и просек: & 468.371 & 130.100 & 5.120 .000 & 1.878 .056 & 3.241 .644 & 29,36 \\
\hline
\end{tabular}

У Србији је поседовање ватреног оружја легално у случају када се ради о врстама чије је поседовање законом допуштено (пиштољи, ловачке пушке) и када је за то прибављена одговарајућа дозвола. Нелегално је оружје чије поседовање није дозвољено правним оквиром (аутоматско оружје, минско-експлозивна средства, пригушивачи), као и оно оружје чије је поседовање дозвољено законом, али грађанин за њега нема уредну дозволу. Додатно, дозволом за поседовање није обухваћено ношење оружја, већ је потребно затражити посебну дозволу (Ђурђевић-Лукић, Тадић, Милић, 2015).

Налази поменутог истраживања Small Arms Survey показују да ce 2018. године у Србији налазило преко три милиона комада малокалибарског оружја у рукама цивила (милион нелегалног и два милиона легалног). Од краја сукоба на простору бивше Југославије до данас, провајдери безбедности предузимали су различите активности и бројне кампање легализације оружја, усредсређујући се на оружје које потиче са ратишта како би одговорили на овај безбедносни изазов (Шапић, Стојановић, 2017; Стојановић, Шекарић, 2019). 


\section{ДИСБАЛАНС МОЋИ: ВАТРЕНО ОРУЖЈЕ И ФЕМИЦИД}

...за жене рат није завриен кад је готов.

Глобални показатељи указују на то да сваке године од ватреног оружја у свету страда око 500.000 особа (300.000 у конфликтима, a 200.000 у мирнодопским условима), од чега су $80 \%$ цивили. Мушкарци су углавном починиоци (у 97\% случајева), док су жртве у $79 \%$ случајева (Racovita, 2015). Они су у 90\% случајева и држаоци оружја. C обзиром на то да се на глобалном плану већина смртних случајева и повреда везаних за (зло)употребу оружја дешава изван куће, улога ватреног оружја у контексту насиља у породици или интимних партнерских односа није у довољној мери истражена. У највећем проценту у сукобима у тзв. неконфликтним окружењима, жртве насиља везаног за ватрено оружје - било оно смртоносно или не - јесу младићи и одрасли мушкарци (WHO, 2002; UNODC, 2011). Жене поседују мале количине оружја, веома ретко су починитељке, а несразмерно су заступљене међу жртвама. Оваква несразмера јасно показује да су жене озбиљно угрожене могућим злоупотребама SALW-a.

Крајем XX века и почетком XXI века сагледавање питања лаког и малокалибарског оружја из родне перспективе улази у академски дискурс, пре свега кроз различите аналитичке приступе феминистичких теоретичара. Бројни аутори покушали су да утврде везу између малокалибарског оружја и родно заснованог насиља над женама у породици и партнерским односима (Farr, Gebre-Wold, 2002; Cukier, 2002; Catalano, 2007). У поменутим радовима оружје се не проблематизује само као средство извршења најтежих кривичних дела - убиства, силовања и сл., већ и као средство мушке надмоћи, застрашивања и контроле, које доприноси одржавању страха и маскулиног идентитета (Alvazzi del Frate, 2011; Shaw, 2013).

Истраживања су показала да ватрено оружје игра значајну улогу у претњама и застрашивању у контексту насиља међу интимним партнерима, као део обрасца насиља, тј. контроле и моћи, који доминантно користе мушкарци према женама (Tjaden, Thoennes, 2000, p. 11; Vetten, 2006; Johnson, Myrna, 2011, p. 71).

\section{Фемицид}

Истраживања фемицида указују на присутне полне разлике и родну димензију злоупотребе ватреног оружја у контексту насиља над женама. Фемицид је термин који се користи од 1970-их година и односи се на убијање жена или девојака, само зато што су жене, чиме се наглашава родна димензија овог дела (Bloom, 2008; Sagot, Carcedo, 2010). Термин се сада широко користи да означи свако убиство жене или девојчице, било од стране интимног партнера, познаника или странца. Осим интимних партнерских убистава, он укљу- 
чује и културолошки специфичне облике убистава, као што су: „смрт због мираза” и „убиство због части”, убиство са силовањем, убиство проститутки, женско чедоморство или селективни абортус, те друге смрти које се према форензичким извештајима јављају као последица насиља према женама и девојкама само на основу њиховог пола, убиство жена сексуалних радница, убиства жена у трговини дрогом, убиства жена и девојака у оружаним сукобима (UNGA, 2012; Спасић, Коларевић, Луковић, 2017).

На основу података Секретаријата Женевске декларације из истраживања којим је обухваћено 111 земаља и територија у периоду од 2007. до 2012. године, сваке године у свету је убијено око 66.000 жена, што представља око $17 \%$ свих намерних убистава (Geneva Declaration Secretariat, 2011). Ово доводи до резултата да је на пет мушкараца убијена једна жена на узорку од 100.000 становника; ова стопа значи да, у просеку, има пет пута више убистава мушкараца него жена. Фемициди се дешавају углавном у приватном окружењу (дом, кућа), а починилац је обично актуелни или бивши партнер. Ватрено оружје је коришћено у једној трећини свих евидентираних убистава жена (Alvazzi del Frate, 2011, p. 114).

Процењује се да присуство ватреног оружја у контексту породичног или партнерског насиља повећава вероватноћу смртног исхода за жене пет до дванаест пута у поређењу са случајевима када ватрено оружје није коришћено (Alvazzi del Frate, 2011). Бројне студије у свету су указале на то да више фактора повећава вероватноћу смртног исхода у партнерском насиљу када је присутно ватрено оружје:

- озбиљност повреда;

- смањена могућност жене да пружи отпор;

- смањене шансе жене да побегне или да непознате особе интервенишу и помогну јој;

- повећане шансе да ће насилник заиста употребити ватрено оружје у случајевима насиља у породици.

У 24 земље за које су доступни потпуни подаци, постоји директна повезаност између стопе фемицида и процента фемицида почињеног ватреним оружјем. Ниска стопа фемицида је често повезана ca peђом употребом ватреног оружја (Campbell, 2003). Женама највећа опасност прети од актуелних или бивших партнера од којих су трпеле хронично насиље и оних који настоје да насиљем спрече женин одлазак или да је казне због одбацивања. Истраживања убистава жена од стране брачног или интимног партнера упутила су на следеће маркере ризика:

- историја партнерског насиља;

- прекид партнерског односа од стране жене;

- упућивање претњи убиством;

- прогањање; 
- доступност ватреног оружја;

- патолошка посесивност мушког партнера;

- незапосленост мушког партнера;

- поремећај менталног здравља (укључујући суицидалност) мушког партнера.

Хронично насиље у вези које мушкарац врши према жени претходница је за око $70 \%$ партнерских убистава и сматра се главним маркером ризика за убиство партнера оба пола (СимеуновићПатић, Кесић, 2016).

\section{Злоупотреба ватреног оружја у контексту насиља- расположиви подаци}

У контексту насиља, ватрено оружје чешће се користи као претња него за директно угрожавање жртве (Hemenway, Azrael, Miller, 2000; Hemenway, 2011). Оружје је присутно и у случајевима прогањања. Прогонитељи могу поседовати оружје и користити га да контролишу и застрашују, али не и да повреде жртве (Meloy, 1998, p. 17). Бројне жртве фемицида су претходно пријављивале претње ватреним оружјем или прогањање (Campbell, Webster, Glass, 2009). Tакође, присуство оружја у кући може довести до смртоносног насиља према женама и девојкама; већа је вероватноћа да ће ватрено оружје послужити за претње и повређивање чланова породице него да би се заштитио дом од провалника (Hemenway, 2011, p. 7). Једна канадска студија из 2010. године је, на основу анализе свих случајева жена које су убијене у периоду од шест година, потврдила да се политиком која ограничава приступ оружју у приватним просторима може смањити ризик од трагичних последица насиља у породици (RCMP, 2002).

У анализи спроведеној у 26 земаља са високим примањима становника и 10 земаља са средње високим примањима становника, Хеменвеј и Милер документовали су јасну повезаност између степена доступности ватреног оружја и стопе убистава - „тамо где је оружје доступније има више убистава" (Hemenway, Miller, 2000). У Сједињеним Америчким Државама (САД), које имају једну од највиших стопа власништва над оружјем, $84 \%$ свих убијених жена убијено је ватреним оружјем, што је двоструко више од глобалног просека (UNODC, 2013). ${ }^{2}$ Вероватноћа да ће „жена према којој је извршено насиље бити убијена од стране насилника (актуелног или бившег партнера) пет пута је већа ако он поседује ватрено оружје” (Mankowski, 2013).

\footnotetext{
${ }^{2}$ UNODC (United Nations Office on Drugs and Crime) 2013. Global Study on Homicide. Trends, Contexts, Data. Vienna. Преузето 20. 6. 2019. https://www.unodc.org/documents/ gsh/pdfs/2014_GLOBAL_HOMICIDE_BOOK_web.pdf
} 
У земљама са високом стопом убистава као што су Бразил, Колумбија, Ел Салвадор, Гватемала и Хондурас - више од 60\% фемицида почињених од 2004. до 2009. године укључивало је употребу ватреног оружја. У САД-у ватрено оружје је коришћено у око половини забележених случајева фемицида од 1999. до 2007. године (Campbell et al., 2009). Истовремено, инциденти који укључују девојке убијене ватреним оружјем најчешће се дешавају у стану (Соупе Beasley, Moracco, Casteel, 2003, p. 358).

У случајевима познатим као фемилицид или убиство-самоубиство, починилац може убити целу своју породицу или породицу жене пре него почини самоубиство. Штавише, када се користи ватрено оружје у контексту насиља, већа је вероватноћа да ће починилац фемицида извршити самоубиство (Mathews, 2004).

У Србији се од 2000. до 2016. године догодило 6 масовних пуцњава, од којих су 5 биле директно усмерене на неког члана породице или интимног партнера. У тих пет пуцњава, укупно је убијено 40, а рањено 28 особа. Жене су чиниле 55\% жртава (Božanić, 2016). На основу базе података Секретаријата Женевске декларације, од 48 држава за које су били доступни поуздани подаци за период од 2007. до 2012. године, Србија је рангирана као седамнаеста по проценту жена убијених ватреним оружјем. Скоро $45 \%$ жена жртава партнерског насиља убијено је ватреним оружјем у Србији 2015. године. ${ }^{3}$ Истраживање виктимизације жена убиством у партнерском односу на подручју Београда показало је да је као средство извршења најчешће коришћено ватрено оружје (60\%), које су учиниоци углавном држали без дозволе (Симеуновић-Патић, Јовановић, 2013).

Прикупљањем и анализом новинских извештаја, Мрежа „Жене против насиља" (даље: Мрежа) дошла је до податка да су, на пример, током 2016. године на територији Србије убијене 33 жене у породичном/партнерском контексту, ${ }^{4}$ а да је у $22,22 \%$ случајева убиство извршено оружјем у нелегалном поседу. Мрежа је навела да су поседовање оружја и приступ ватреном оружју показатељи високог ризика од смртног исхода насиља, те су у свету одавно уврштени међу показатеље за процену безбедносних ризика у случајевима насиља у породици. ${ }^{5}$ Чињеница је и да се 5 од 9 жена које су усмрћене ватреним оружјем претходно обраћало надлежним институцијама

\footnotetext{
${ }^{3}$ Irena Vojačkova Solorano, Oružje i nasilje u porodici, http://www.b92.net/info/moj_ ugao/index.php?yyyy=2016\&nav_category=166\&nav_id=1154678, 15. април 2019.

${ }_{4}^{4}$ Сваке наредне године, све до данас, број жена убијених у породично-партнерском контексту кретао се између 30 и 40.

${ }^{5}$ Квантитативно-наративни извештај за 2016. годину, http://www.zeneprotivnasilja. net/images/pdf/FEMICID-Kvantitativno-narativni_izvestaj_za_2016_godinu.pdf,14. април 2019.
} 
тражећи заштиту и помоћ. Извештаји о фемициду показују да је у периоду од 2012. до 2016. године 33\% убистава у породично-партнерском односу почињено ватреним оружјем. За 5 година убијено је 170 жена у контексту насиља, а њих 57 ватреним оружјем. Посебно забрињава податак да је у већини случајева у којима су жене усмрћене ватреним оружјем насиље претходно пријављивано (Спасић, Тадић, 2017). Мрежа је у својим квантитативно-наративним извештајима о фемициду навела да су поседовање оружја и приступ ватреном оружју показатељи постојања високог ризика од смртног исхода насиља, те су у свету одавно као показатељи уврштени у листе за процену безбедносних ризика у случајевима насиља у породици. ${ }^{6}$

Представљени налази из бројних истраживања, а посебно оних у којим су се аутори бавили утицајем малокалибарског оружја на насиље у породици, спроведених у земљама западног Балкана почетком 2000-их - указују на повезаност поседовања нелегалног ватреног оружја и обима насиља у породици. Лака доступност малокалибарског и лаког оружја, њихова непозната локација и убојитост представљају озбиљну претњу за личну безбедност појединаца, а у контексту насиља у породици, посебно су угрожене жене као жртве.

Истовремено, искуства појединих земаља, као што су Аустралија, Канада, Јужна Африка и Тринидад и Тобаго показују да хармонизовање домаћих закона који регулишу ношење/поседовање оружја са потребом заштите од насиља у породици, односно пооштравање законских услова у овој области, може довести до смањења обима насиља у породици. Канада је пооштрила законе о поседовању оружja 1995. године и до 2003. године стопа убистава коришћењем оружја пала је за укупно $15 \%$, а за $40 \%$ опала је стопа убиства жена у контексту породичних и партнерских односа (RCMP, 2002).

Представљени резултати спроведених истраживања указују на то да присуство ватреног оружја, било у легалном или нелегалном поседу, може директно утицати на повећање обима (распрострањености) и на карактеристике (врсту, интензитет и последице) насиља у породици и партнерским односима. Та чињеница указује на неопходност успостављања контроле од стране надлежних институција над поседовањем и коришћењем ватреног оружја које се налази у поседу грађана.

\footnotetext{
${ }^{6}$ Мрежа „Жене против насиља” (2016). ФЕМИЦИД - Квантитативно-наративни извештај за 2016. годину. Преузето 29. 8. 2019. http://www.zeneprotivnasilja. net/images/pdf/FEMICID-Kvantitativno-narativni_izvestaj_za_2016_godinu.pdf
} 


\section{КОНТРОЛА ВАТРЕНОГ ОРУЖЈА И НАСИЉЕ НАД ЖЕНАМА У СРБИЈИ - ПРАВНИ ОКВИР}

Контрола ватреног оружја (реалне процене заступљености нелегалног оружја у поседу грађана, његова легализација, контрола његовог поседовања, односно ношења и употребе) и спречавање његове злоупотребе у контексту насиља - подразумева дефинисање специфичних поступака и процедура у оквиру националног законодавства.

Активности државних институција у вези са контролом ватреног оружја, ватреног оружја и насиљем у породици у Србији одвијају се у амбијенту који, у нормативном смислу, директно дефинишу два закона: Закон о оружју и мунищији и Закон о спречавағу насиьа у породиии.

\section{Закон о оружју и мунииији}

Закон о оружју и муницији усвојен је 2015. године, након више од 20 година важења претходног закона из 1992. године. Њиме је унапређена процедура издавања дозвола за поседовање оружја, по којој поседник оружја мора имати оправдан разлог за то - то могу бити лица која „учине вероватним” да би њихова безбедност могла бити угрожена због посла који обављају или неких других околности.

Једна од најзначајнијих новина у Закону је провера и праћење здравствене способности лица за поседовање оружја. Лекарско уверење о здравственој способности за држање и ношење оружја мора се обнављати на сваких 5 година, а изабрани лекар има обавезу да обавести МУП уколико је код поседника ватреног оружја наступила измена здравственог статуса која може утицати на његову способност за држање и ношење оружја, сходно Правилнику о утврђивању здравствене способности физичких лица за држане и ношење оружја (2016). Истовремено, МУП има обавезу да здравственој установи, односно изабраном лекару, доставља податке о лицима која поседују оружје.

У првој верзији Правилника, провера здравствене способности укључивала је преглед псхијатра и психолога, да би каснијим изменама и допунама био избачен преглед психолога, док психолошки интервју и процену особина личности обавља психијатар или неуропсихијатар. Листа психијатријских, психолошких и неуролошких индикација која су контрадикторна издавању лекарског уверења опсежна је и свеобухватна, а међу побројаним стањима су и алкохолизам и зависност од психоактивних супстанци. Лице које је добило негативну здравствену процену нови захтев за преглед може поднети након 6 месеци, што је кратак рок да би се значајно изменила већина стања која су наведена у Правилнику као препрека издавању дозволе. Такође, период од 5 година за обнављање лекарског уверења по- 
тенцијално је дугачак, с обзиром на то да у овом периоду може доћи до озбиљних промена у психолошком статусу особе.

У домену заштите од родно заснованог насиља, у Закону о оружју и муницији значајне су одредбе које се односе на пооштрене критеријуме, односно на услове за поседовање оружја и увођење безбедносно-оперативне провере. ${ }^{7}$

Закон о оружју и муницији (члан 3) садржи и одредбу о легализащијu, као процесу регистрације или предаје нерегистрованог оружја или муниције, у оквиру кога лица нису дужна да доказују порекло оружја и муниције, а не могу бити кривично или прекршајно гоњена за нелегално набављање, држање и ношење оружја и муниције. Ова процедура треба да омогући транспарентну контролу поседовања ватреног оружја. Легализацију расписује министар унутрашњих послова у случају када то захтевају „разлози очувања безбедности грађана и јавног реда и мира" (члан 46). Претпоставља се да грађани имају низак степен поверења у способност институција да им пруже безбедност, због чега не желе да га предају или предају само део оружја које поседују (Шапић, Стојановић, 2017).

\section{Закон о спречавағу насиља у породици}

У складу са обавезама преузетим ратификацијом Истанбулске конвениије ${ }^{8}$, Србија је извршила измене и допуне Кривичног закони$\kappa a$, донела Закон о спречавању насиља у породици (2016). Изменама и допунама важећег Кривичног законика уведена су три нова кривична дела: прогањање, полно узнемиравање и принудни брак.

Основни циљеви доношења Закона о спречавању насиља у породищи били су: 1) да се премости правни вакуум који постоји од пријаве насиља или опасности од насиља до почетка судског поступка; 2) да се у правни систем уведе стандард према коме учинилац на-

\footnotetext{
7 Услови су наведени у члану 11 Закона: „да је физичко лице здравствено способно за држање и ношење оружја; да није правноснажно осуђивано на казну затвора за кривична дела против живота и тела, против слобода и права човека и грађанина, против полне слободе, против брака и породице, против имовине, против здравља људи, против опште сигурности људи и имовине, против уставног уређења и безбедности Републике Србије, против државних органа, против јавног реда и мира за које је прописана казна затвора; да није правноснажно кажњавано у последње четири године за прекршаје из области јавног реда и мира за које је прописана казна затвора; да на основу безбедносно-оперативне провере у месту пребивалишта, боравишта, месту рада, својим понашањем не указује на то да ће представљати опасност за себе или друге и јавни ред и мир; да има услове за безбедан смештај и чување оружја".

8 Закон о потврђивању Конвенције Савета Европе о спречавању и борби против насиља над женама и насиља у породиии, http://www.parlament.gov.rs/upload/ archive/files/cir/pdf/predlozi_zakona/2246-13.pdf, 15. 4. 2019.
} 
сиља не сме остати у кући, не само када је насиље већ учињено већ и када постоји непосредна опасност од насиља; 3) остваривање принциипа нулте толеранције на насиље. Закон треба да створи услове који ће омогућити ефикасно управљање ризиком од насиља. Процена ризика и изрицање хитних мера, оснивање група за координацију и сарадњу, предвиђање израде индивидуалног плана заштите и подршке жртви и јединствена евиденција података о насиљу у породици основ су онога што Истанбулска конвенција (у чл. 51) назива управљање ризиком од насиља.

Кривичноправна заштита садржи низ посебних одредаба чија је сврха да успостави континуитет заштите жртве од настанка насиља (или претње да до њега дође) до тренутка када ће жртва бити у стању да се опорави, а учинилац насиља санкционисан. Поред физичког, психичког и сексуалног насиља, законом је унет и елеменат економског насиља (сходно члану 3 Истанбулске конвенщије).

Спречавање насиља у породици предвиђа скуп мера које се примењују да би се открила непосредна опасност од насиља, односно мера које се примењују ако је та опасност откривена. Закон уреЂује мултиресорну сарадњу и предвиђа круг органа и установа које се старају о заштити и пружању подршке жртви, почев од обавештавања о њеним правима, преко пружања правне помоћи и активности чија је сврха опоравак и оснаживање. У Закону о спречавағу насиља y породици прецизиран је круг лица која могу бити жртве. ${ }^{9}$

Посебан поступак за спречавање насиља у породици (чл. 1220) представља примену неких од најважнијих решења из Истанбулске конвенщије. Надлежни полищијски службеник задужен за спречавање насиља у породици, као специјално обучен координатор који спречава насиље и стара се о заштити жртве, сачињава процену ризика од непосредне опасности од насиља и посебно утврђује да ли потенцијални насилник поседује оружје (чл. 51 Истанбулске конвенције), чиме се настоји предупредити могући смртни исход насиља.

Закон предвиђа изрицање хитних мера учиниоцу насиља, којима се он лишава извесних права науштрб заштите жртве насиља. Хитне мере - један од института којим се спречава понављање насиља или могућност да до њега дође - имају превентиван карактер, а њихова сврха је да се жртва насиља у породици благовремено и

\footnotetext{
${ }^{9}$ То је лице у садашњем или ранијем брачном, ванбрачном или партнерском односу, или лице са којим је учинилац насиља крвни сродник у правој линији, а у побочној линији до 2. степена или са којим је сродник по тазбини до 2. степена, коме је усвојитељ, усвојеник, хранитељ или храњеник). Насиље у породици постоји и онда када је учињено према сваком другом лицу са којим учинилац живи или је живео у заједничком домаћинству, при чему то не мора бити садашњи или бивши супружник, нити крвни, грађански или тазбински сродник.
} 
ефективно заштити. Сврха индивидуалног плана заштите и подршке жртви јесте да спречи могуће насиље према жртви или његово понављање и пружи жртви психосоцијалну и другу подршку.

Спречавањем насиља у породици објективном проценом ризика, израдом индивидуалног плана заштите жртве и координисаним деловањем надлежних органа треба да буде створен безбедносни амбијент који ће заштитити жртву од најтежих облика насиља, али и од злоупотребе ватреног оружја у контексту насиља у породици.

\section{Контрола ватреног оружја и обим насиља у породищи у Србији. Како успоставити везу?}

Постојећи законски оквир и његова решења стварају тек предуслове за успостављање контроле ватреног оружја и смањење обима насиља. Да би се успоставила контрола, неопходно је, најпре, у што већој мери нелегално оружје „превести” у легалне токове, континуираним, планским и организованим активностима његовог прикупљања и поступцима легализације у којима се неће тражити његово порекло. Акције прикупљања нелегалног оружја морале би бити праћене објавом аналитичких података надлежних државних органа о процењеном броју нелегалног оружја у поседу грађана, о броју и последицама инцидената повезаних са злоупотребом оружја, полу и старости жртава и починилаца, најчешћим локацијама и другим информацијама које би помогле у сагледавању и решавању проблема. Увођење оружја у легалне токове омогућава периодично преиспитивање, анализу и/или пооштравање критеријума за поседовање оружja, посебно узимајући у обзир специфичности фемицида извршених ватреним оружјем. Контрола ватреног оружја налаже и спровођење континуираних специјалистичких лекарских прегледа лица (у краћем временском периоду у односу на предвиђених 5 година) која поседују оружје и размену информација између полиције и изабраног лекара о променама у здравственом статусу које искључују добијање дозволе за поседовање оружја или представљају услов за одузимање постојеће дозволе. Успостављање и спровођење контроле ватреног оружја подразумева сталне превентивне активности полицијских службеника и периодичне безбедносно-оперативне провере на безбедносном сектору (у локалној заједници) усмерене како према лицима која поседују легално оружје тако и према лицима за које постоје индиције о поседовању нелегалног ватреног оружја. Превентивне активности и благовремене безбедносне информације (индиције) посебно су значајне у сагледавању количине ватреног оружја у нелегалном поседу, његове доступности и препродаје у оквиру кријумчарских канала.

Међутим, спровођење искључиво активности контроле ватреног оружја не може утицати на смањење обима насиља у породици и 
партнерским односима, уколико није праћено превентивним и законским мерама заштите од насиља. То подразумева, између осталог, идентификовање, надгледање и континуирано „праћење” (од стране полиције и центара за социјални рад) породица у локалној заједници за које постоје или су потврђене индиције о присуству различитих облика насиља или лица која су склона насилничком понашању, или пак поседују оружје. Свака пријава за насиље или информација о присуству ватреног оружја у домаћинству наглашава потребу и значај превентивних активности у том контексту, због чега је треба евидентирати, узимајући све неопходне информације о контексту насиља и евентуалним претњама убиством и индицијама које упућују на присуство оружја у кући/домаћинству. Пријаве за насиље (психичко, претње физичким насиљем) налажу да се управљање ризиком од насиља спроводи сходно постојећим протоколима и чл. 51 Истанбулске конвениије, односно да се поседовање оружја и приступ ватреном оружју у листи за процену безбедносних ризика у случајевима насиља у породици у сваком конкретном случају означе као показатељи постојања високог ризика од смртног исхода насиља.

Синергична и синхронизована примена постојећих законских решења од стране надлежних државних органа на плану заштите од насиља и контроле ватреног оружја требало би да ојача поверење грађана у институције, допринесе ефикаснијем прикупљању и легализацији ватреног оружја и објективној процени безбедносних ризика од употребе ватреног оружја у контексту насиља. При томе треба имати у виду да жртвама подједнако прети опасност и од оружја које насилник држи у легалном поседу и од оружја које се може набавити на илегалном тржишту. Због тога су успостављање пуне контроле од стране надлежних органа над процедурама набавке, складиштења и поседовања оружја, спречавање кријумчарења и његове препродаје, сложене здравствене процедуре и чешће провере испуњености здравствених услова лица која траже дозволу или поседују ватрено оружje, превентивне активности и објективна процена ризика - преуслови за ефикаснију заштиту жртава и смањење обима насиља.

\section{ЗАКЉУЧНА РАЗМАТРАЬА}

Присуство ватреног оружја у кући представља ванредно отежавајућу околност за жртву насиља, али и инструмент којим се одржавају традиционални обрасци понашања и доминација маскулинитета. Сузбијање овог проблема мора подједнако укључити смањивање количине нелегалног и легалног ватреног оружја у једном друштву. Разматрање начина на који употреба оружја утиче на мушкарце и жене пружа важан допринос у креирању јавних политика контроле 
ватреног оружја и предузимању интервенција на плану спречавања и сузбијања његове злоупотребе (Bastick, Grimm, Lazarević, 2008).

Доследна контрола примене Закона о оружју и мунищији од изузетног је значаја, а психолошко стање лица која поседују оружје је кључно питање за његову ефикасну примену. Неповерење у способност институција да пруже безбедност грађанима јавља се као један од кључних разлога за поседовање оружја, али истовремено као један од главних разлога зашто жртве родно заснованог насиља не пријављују насиље. Професионално и сензибилисано поступање службеника институција у случајевима родно заснованог насиља, а посебно у оним који укључују употребу или претњу оружјем, од изузетне је важности за јачање поверења у институције.

$\mathrm{y}$ вези са мерама против насиља у породици садржаним у законодавном оквиру контроле SALW-a, потребно је спровести процену делотворности и усклађености нормативног и институционалног одговора у погледу ограничавања приступа ватреном оружју у контексту насиља у породици. Неопходно је и преиспитати праксе које се односе на складиштење и чување оружја. Потребно је, такође, усвојити и нову Стратегију контроле лаког и малокалибарског наоружаға, јер је претходна престала да важи још 2015. године. Неопходно је формулисати препоруке за унапређење кохерентности законодавног одговора на ризике узроковане присуством ватреног оружја у породичном окружењу, с посебно усмереном пажњом на праксе превенције и успостављање јаче везе између законодавног оквира контроле SALW-a, те закона којима се регулише одговор на насиље у породици и партнерско насиље.

\section{ЛИТЕРАТУРА}

Alvazzi del Frate, A. (2011). When the Victim Is a Woman. In Geneva Declaration Secretariat. Global Burden of Armed Violence: Lethal Encounters. Cambridge: Cambridge University.

Bastick, M., Grimm, K., Lazarević, J. (2008). Armed Violence against Women. Global Burden of Armed Violence. Geneva: Geneva Declaration Secretariat, 109-124.

Bloom, S. (2008). Violence against Women and Girls: A Compendium of Monitoring and Evaluation Indicators. Chapel Hill, NC: MEASURE Evaluation.

Богетић, Д., Митровић, Ј., Николић, С. (2018). Ставови младих у Србији према проституцији, родној равноправности и феминизму у 2016. години [Attitudes of Young People in Serbia about Prostitution, Gender Equality and Feminism in 2016]. Теме. XLII(3), 741-761.

Božanić, D. (2016). Gender and SALW in South East Europe. Belgrade: UNDP, SEESAC.

Campbell, J. (2003). Risk Factors for Femicide in Abusive Relationships: Results from a Multisite Case Control Study. American Journal of Public Health. 93(7), 1089-1097.

Campbell, J., Webster, D., Glass, N. (2009). The Danger Assessment: Validation of a Lethality Risk Assessment Instrument for Intimate Partner Violence. Journal of Interpersonal Violence, 24 (4), 653-674. 
Catalano, S. (2007). Intimate Partner Violence in the United States. Washington, DC: Bureau of Justice Statistics, United States Department of Justice.

Coyne-Beasley, T., Moracco, K.E., Casteel, M. (2003). Adolescent female homicide: A population-based study. Archives of Pediatrics and Adolescent Medicine, $157,355-360$.

Cukier, W. (2002). Gender Perspectives on Small Arms Proliferation and Misuse: Effects and Policies. In V. A. Farr, K. Gebre-Wold (eds.). Gender Perspecitves on Small Arms and Light Weapons: Regional and International Concerns (25-42). Bonn: International Centre for Conversion.

Ђурђевић-Лукић, С., Тадић, М., Милић, Т. (2015). „Оружје на мети”: Злоупотреба ватреног оружја у Србији ["Weapons on Target": Misuse of firearms in Serbia]. Београд: UNDP, SEESAC.

Farr, V. A., Gebre-Wold, K. (Eds.) (2002). Gender Perspectives on Small Arms and Light Weapons: Regional and International Concerns. Bonn: Bonn International Centre for Conversion.

Florquin, N. (2011). A Booming Business: Private Security and Small Arms. In Small Arms Survey 2011: States of Security (149-178). Cambridge: Cambridge University Press.

Geneva Declaration Secretariat (2008, 2011). Global Burden of Armed Violence. Geneva.

Hemenway, D., Azrael, D., Matthew M. (2000). Gun Use in the United States: Results from Two National Surveys. Injury Prevention, 6, 263-267.

Hemenway, D., Miller, M. (2000). Firearm Availability and Homicide Rates across 26 High-Income Countries. Journal of Trauma, Injury, Infection and Critical Care, 49(6), 985-988.

Hemenway, D. (2011). Risks and Benefits of a Gun in the Home. American Journal of Lifestyle Medicine. 5(6), 502-511.

Johnson, H., Myrna D. (2011). Violence against Women in Canada: Research and Policy Perspectives. Oxford: Oxford University Press.

Karp, A. (2018). Estimating Global Civilian - HEID Firearms Numbers. Geneva: Small Arms Survey.

Котарлић, Д., Јоксимовић, С. (2015). Усклађивање законске регулативе Републике Србије са Стратегијом ЕУ за борбу против недозвољеног сакупљања и промета лаког и стрељачког наоружања и муниције - степен усклађености и неопходне мере [Harmonization of the legislation of the Republic of Serbia to the EU Strategy to combat illicit collection and circulation of small arms and small arms and ammunition - the degree of compliance and the necessary measures]. Војно дело. 67(3), 251-270. DOI:10.5937/vojdelo1503251K

Mankowski, E.S. (2013). Antecedents to gun violence: Gender and culture. In Gun violence: Prediction, prevention and policy. Washington, D.C.: American Psychological Association. 13-17.

Mathews, S. (2004). Every Six Hours a Women is Killed by Her Partner: A National Study of Female Homicides in South Africa. MRC Policy Brief, No. 5, June.

Meloy, J. (1998). The Psychology of Stalking. In J. Meloy (ed.). The Psychology of Stalking: Clinical and Forensic Perspectives (28-51). San Diego: Academic Press.

PAHO (Pan American Health Organization) (2005). Gender, Health, and Development in the Americas: Basic Indicators 2005. Washington, DC: PAHO

Racovita, M. (2015). Lethal Violence against Women and Girls. In Geneva Declaration Secretariatt, Global Burden of Armed Violence 2015: Every Body Counts. Cambridge: Cambridge University. Dostupno na:

RCMP (Royal Canadian Mounted Police) (2002). Research Summary: Domestic Violence Involving Firearms. Ottawa: RCMP. 
Sagot, M., Carcedo, A. (2010). When Violence against Women Kills: Femicide in Costa Rica, 1990-1999. In R. Fregosa, C. Bejarano (Eds.): Terrorizing Women: Femicide in Latin America. Durham: Duke University Press.

Shaw, M. (2013). Too Close to Home: Guns and Intimate Partner Violence. In Small Arms Survey 2013: Everyday Dangers. Cambridge: Cambridge University Press.

Симеуновић-Патић, Б., Јовановић, С. (2013). Убиство жене у партнерском односу [Murder of a woman in a partnership]. Београд: Институт за криминолошка и социолошка истраживања.

Симеуновић-Патић, Б., Кесић, Т. (2016). Криминалистичка виктимологија [Criminalistic Victimology]. Београд: Криминалистичко-полицијска академија.

Службени гласник PC. Бр. 20 (2015). Закон о оружју и муницији [Law on Weapons and Ammunition]. Београд: Службени гласник PC.

Службени гласник РС. Бр. 94 (2016). Закон о изменама и допунама Кривичног законика [Law on Amendments to the Criminal Code]. Београд: Службени гласник РС.

Службени гласник РС. Бр. 85 (2005), 88 (2005), 107 (2005), 72 (2009), 111 (2009), 121 (2012), 104 (2013), 108 (2014). Кривични законик [Criminal Law]. Београд: Службени гласник РС.

Службени гласник РС. Бр. 94 (2016). Закон о спречавању насиља у породици [Law on the Prevention of Domestic Violence]. Београд: Службени гласник PC.

Службени гласник РС. Бр. 25 (2016), 79 (2016). Правилник о утврђивању здравствене способности физичких лица за држање и ношење оружја [Rulebook on determining the physical fitness of physical persons for holding and carrying weapons]. Београд: Службени гласник РС.

Спасић, Д., Тадић, М. (2017). Злоупотреба оружја и родно засновано насиље [The misuse of weapons and gender-based violence]. Београд: Центар за истраживање јавних политика.

Спасић, Д., Коларевић, Д., Луковић, 3. (2017). Фемицид у партнерским односима [Femicide in partner relationships]. Темида, 20(3), 411-434. doi:10.2298/ TEM1703411S.

Стојановић, Ф., Шекарић, Н. (2019). Улога полиције у сузбијању проблема лаког и малокалибарског оружја у Републици Србији и на Западном Балкану [The role of the police in combating the problem of small arms and light weapons in the Republic of Serbia and the Western Balkans]. Kултура полиса, ХIV(38), 615-634.

Шапић, Ј., Стојановић, Ф. (2017). Грађани на стражи: Локални приступ у смањивању распрострањености оружја [Citizens on guard: A local approach to reducing the proliferation of weapons]. Београд: Центар за истраживање јавних политика.

Tjaden, P., Thoennes, N. (2000). Extent, Nature and Consequences of Intimate Partner Violence: Findings from the First National Violence against Women Survey. NCJ No. 181867. Washington, DC: National Institute of Justice, United States Department of Justice.

UNGA (United Nations General Assembly) (1993). Declaration on the Elimination of Violence against Women. A/RES/48/104 of 20 December.

UNGA (United Nations General Assembly). 2012. Report of the Special Rapporteur on Violence against Women, Its Causes and Consequences, Raschida Manjoo. A/HRC/20/16 of 23 May.

UNODC (United Nations Office on Drugs and Crime). (2011). Global Study on Homicide: Trends, Contexts, Data. Vienna: UNODC. 
Vetten, L. (2006). Mapping the Use of Guns in Violence against Women: Findings from Three Studies. African Security Review, 15(2), 86-92.

WHO (World Health Organization). 2002. World Report on Violence and Health. Geneva: WHO.

\title{
FIREARMS CONTROL AND GENDER-BASED VIOLENCE: THE MISSING LINK?
}

\author{
Danijela Spasić \\ University of Criminal Investigation and Police Studies, Belgrade, Serbia
}

\begin{abstract}
Summary
The omnipresent possession of weapons in the world, especially in a post-conflict society, points to numerous social problems and processes - from the process of reconciliation and peace building, through human rights and the situation of vulnerable groups, the rise in violence, to the reform of the security sector and the rule of law.

The prevalence, the lack of a security culture and the disproportionate attitude towards weapons, its daily abuse in conflicts and within the family, including gender-based violence, arms smuggling and organized crime with an underdeveloped strategic position, are just some of the threats to human, national and regional security. After the war in the region in the early 2000s, the estimates indicated the presence of over a million pieces of firearms and a large quantity of ammunition in the possession of Serbian citizens.

At the same time, the demographic of domestic violence pointed to the consequences of the misuse of firearms in the context of family and partner violence. A large number of women's killings (annually between 30 and 40) also raised the issue of the possession of (non) legal weapons, as well as the adequate response of institutions to the prevention of fatal outbreaks. On the basis of the fact that Serbia passed the Law on Weapons and Ammunition in 2015 (after more than 20 years of validity of the old 1992 Law), in 2013 it ratified the Istanbul Convention and adopted the Law on the Prevention of Domestic Violence in 2016, and the analysis of the descriptive statistics on the death of women by murder in the context of domestic violence, the analytical approach in this paper focuses on seeking the answer to the question: does the existing legislative framework provide adequate protection for victims of violence against the misuse of firearms?

The findings of this study indicate the need to enhance the coherence of the legislative response to the risks posed by the presence of firearms in the family context, with a particular focus on prevention practices, as well as establishing stronger links between the legislative framework for the control of firearms and the laws governing the response to domestic violence and partner violence.

Some of these challenges have been addressed by the new Law on Arms and Ammunition, the Law on the Prevention of Domestic Violence and the Law on Private Security, the Criminal Code, and the National Action Plan for the implementation of United Nations Security Council Resolution 1325 (2017-2020).
\end{abstract}

